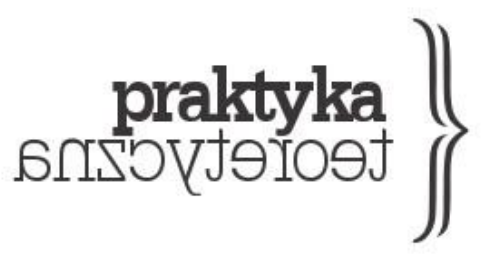

ISSN 2081-8130

DOI: $10.14746 /$ prt.2018.1.9 www.praktykateoretyczna.pl

\title{
BETWEEN MONEY AND SOVEREIGNTY: IS A NEW MONETARY THINKING NEEDED TO INSTITUTE THE COMMON?
}

\section{STEFANO LUCARELLI}

\begin{abstract}
The diffusion of alternative financial and credit circuits, in which the money favours the self-management of social wealth, may curb the expropriation caused by processes of abnormal indebtedness that increasingly characterise economic systems. The article proposes an examination of four experiences with complementary currencies that have sprung up in Europe after the recent crisis, distinguishing between local currencies (Sardex, SoNantes and Sol Violette) and crypto coins (Bitcoin). The possibility of taking advantage of the monetary know-how that animates various experiences (like crypto coins and local clearing houses) would contribute to the re-thinking money as a social institution. Three main topics are discussed: 1. the "political technologies" in which the alternative monetary circuits consist; 2 . democratic participation in the decision-making processes that characterise them; and 3. the meaning of the sovereignties that they potentially define.
\end{abstract}

Keywords: complementary currencies, Bitcoin, Sardex, Sol Violette, SoNantes, the common. 


\section{Introduction}

It is not an easy task to formulate a definition of money since it is a complex entity, an institutional structure that can perform more than one function. This, for example, is how Bianchi presents this fact:

By money we mean everything that is generally accepted as means of payment for goods and services and as an instrument of the debt repayment. [...] It may seem paradoxical, but because money performs more than one function and since there is no consensus among economists on the pre-eminence of one function or other (or all of them), there is therefore no consensus on the univocal definition of monetary aggregates, even restricted to a very definite historically institutional situation. Different approaches to the role of money in the system bring about different specifications of the various goods and financial activities that constitute the monetary aggregate (Bianchi 1982, 91-92).

In other words, money is anything that is widely used in transactions to exchange value, but it functions not only as a medium of exchange or a unit of account, but also as a store of value.

This open-mindedness, however, is not common among economists, who rather tend to establish a particular definition of money, conceived simply as means of exchange. In other words, its characteristics would be theoretically restricted exclusively to its transactional function. As John Maynard Keynes stressed, men should intend money as a mere intermediary. The problem is that money is actually managed as wealth to store.

\footnotetext{
It is not easy, it seems, for men to apprehend that their money is a mere intermediary, without significance in itself, which flows from one hand to another, is received and is dispensed, and disappears when its work is done from the sum of a nation's wealth (Keynes 1923, 124).
}

Mainstream economists that regard money in its mechanical and often simplified sense (as in the neo-classical model) neglect de facto that money may be used as store of value for a very long time. 
In the history of capitalism, deep financial crises give rise to a situation in which money is not spent and debts are not paid. When uncertainty prevails, money is sought after and withheld to the preference of all else. It is not merely a change in the behaviour of economic agents, it depends rather on a peculiar form of monetary institutions: in capitalism money is established as a store of value. Economic historians teach us that unlike the other two functions of money (as unit of account and means of payment), the store of value is not a permanent and general feature of all monetary systems, but a distinctive feature of capitalism (Amato and Fantacci 2012a).

In the face of economic crisis, numerous attempts have been made to reconsider and institute alternative monetary circuits, whether as local clearing houses, crypto-coins, vouchers or assets intended to be spent in specific local areas and that sometimes are guaranteed by sovereign entities, like Local Councils. ${ }^{1}$ This, undoubtedly, is a vital signal for those who hold dear the possibility of constructing forms of socialisation that do not legitimise the exploitation of one person by another, but rather promote models of cooperation and a valorisation of resources that satisfy notably collective needs.

The purpose of my essay is to illustrate the intellectual endeavour that has engaged me for a long time now and which I have developed as part of a European project, ${ }^{2}$ i.e. the possibility of taking advantage of the monetary know-how that animates various experiments (like crypto coins and local clearing houses) by evaluating the particular ability to create a synthesis that would contribute to re-thinking money as a social institution.

The diffusion of alternative financial and credit circuits, in which the money favours the self-management of social wealth, may in fact curb a perverse mechanism, namely: the expropriation caused by processes of abnormal indebtedness that increasingly characterises our economic systems.

Therefore, first of all, I conduct a close examination of the main experiments with complementary currencies that sprung up in Europe after the recent crisis, making sure to distinguish between local currencies and crypto coins. I address some problematic issues characteristic of the cases studies I present below. These issues concern three main topics:

\footnotetext{
1 A nimble introductory reading is the book by Lietaer and Kennedy (2012).

2 http://dcentproject.eu/. A project aimed at creating instruments that would favour decision-making processes done by, and the political and social participation of, European citizens. D-CENT was based on a bottom-up approach that enhances the development of long-lasting strategies that enable the management of goods and services as commons. One of the instruments developed by D-CENT is a set of digital social currencies that can be used in various contexts, but that use the same technologies.
} 
1. the "political technologies" in which the alternative monetary circuits consist;

2. democratic participation in the decision-making processes that characterise these technologies;

3. the meaning of the sovereignties that they potentially define.

Some questions born of that reflection deserve to be addressed immediately, although I will not be able to answer them thoroughly: ${ }^{3}$ as sub-sovereign entities, are complementary currencies destined to remain merely a form of monetary resistance to official monetary circuits? In other words, can they be interpreted just as a defection or exodus mechanism from the present situation, to use an interesting expression by Christian Marazzi? ${ }^{4}$ And, if so, what kind of defection are we talking about? Starting from these experiments, can we redefine the concept of monetary sovereignty and that of state sovereignty? And, if so, in view of what? How can we prevent complementary currencies from gradual becoming forms of naive or strongly identitarian localism ${ }^{5}$

\section{On complementary currency: some case studies}

Some different monetary forms that are complementary to official currencies have recently emerged in Europe in response to the impact of the current financial crisis in the credit system. They have been variously labelled as social, local, alternative monies. However, the meaning of these currencies remains to be discussed. On the one hand, the new monies have been promoted as innovative tools for socio-territorial policies, with a focus on localist, anti-globalist or anti-capitalistic values. On the other hand, the emphasis on the value of monies as instruments of alternative territorial development runs the risk of overshadowing issues concerning the specific features of currency projects. What is needed is a more

3 The issues in question emerged mainly during the Convegno sulla Moneta del Comune (Conference on the Common Currency) held in Macao on the 21-22/06/2014 in the lectures of Christian Marazzi and Carlo Vercellone: http://quaderni.sanprecario.info/tag/convegno-moneta-del-comune/.

${ }^{4}$ Marazzi here uses a concept introduced by Paolo Virno, who summarises exodus as follows: "I use the term exodus here to define mass defection from state, the alliance between general intellect and political action, and a movement toward the public sphere of intellect" (Virno 1996).

${ }^{5}$ Identitarian localism in particular may develop into racism and discrimination. 
accurate reflection on the institutional implications of different types of currencies, in particular concerning the liability of those who hold them to earn or pay an interest. In times of crisis, money creation itself can turn out to be a trap, which literally leads to a war for liquidity. As Fantacci (2016) maintains:

\begin{abstract}
This "competitive struggle for liquidity" provides a crude picture of what we now call the "liquidity trap": a situation in which money hoarding proceeds unrestrained, and conventional monetary policies are incapable of reversing or even arresting it. Any injection of liquidity is immediately drained by the unquenchable thirst of individuals and governments, without appreciable expansionary effects on expenditure, prices, or production. Consumption and investment are postponed, as long as there is an expectation of a further fall in prices. However much money may be put into circulation, it immediately stops circulating: it is neither spent nor invested, but merely hoarded (Fantacci 2016, 5-6).
\end{abstract}

Facing this credit crunch we have witnessed extremely interesting experiments that given rise to alternative monetary circuits able to embed locally. The most famous model is the Wir circuit (Studer 2006 [1998]) that was created in Switzerland in 1934 and whose goal was to limit the effects of the Great Depression on small and medium-sized enterprises. It is a system of exchange between companies - therefore a B2B (business to business) model that encourages transfers between production and commercial units through the multilateral compensation of debts and credits. This mechanism enables liquidity management

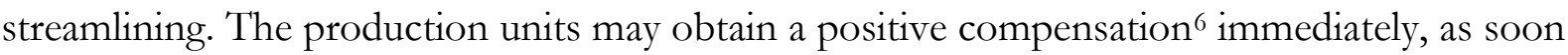
as they sell the goods or services to other circuit participants. Thus they acquire a Wir credit, which serves as means of payment. This circuit allows companies with a production surplus to make contact with other companies in need of their resources. This is how the transactional network works (fig. 1). The central office - which acts as a clearing house establishes the credit limits for each company.

Since 1936, the Wir circuit has been a bank under Swiss law, despite the fact that its emissions are neither guaranteed nor convertible into money as legal tender, that is Swiss

\footnotetext{
6 "All participants sign up for a membership and start with a balance of zero WIR-franc in their current account. They can start to sell goods or services to another member of the WIR network and receive WIRFrancs in return. The buyer's bank account is debited and the seller's bank account is simultaneously credited by the same amount." See http://community-currency.info/en/currencies/wir-bank/
} 
francs. Since 1999, Wir Bank has also starting offering, in addition to Wir currency, banking services in Swiss francs. Since 2000, these are also available for individuals, not only small and medium enterprises. Wir operates as a cooperative. The prices of all goods and services are expressed in "Wir credits". The employment of this circuit follows a trend that, compared to the Swiss economy flow, turns out to be counter-cyclical: when the circulation of franc slows down (for example due to an economic crisis), Wir circulation grows. This results, in this case, in the fact that the complementary currency contributes to economic stability. ${ }^{7}$

Fig. 1. A circuit B2B

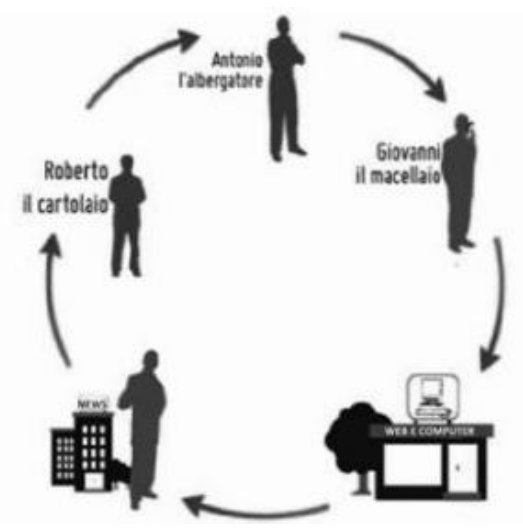

Source: www.sardex.net (January 2013)

[Roberto, the stationer; Antonio, the hotel keeper; Giovanni, the butcher]

On this model a recent experience has been built and diffused in a place historically characterised by credit crunches and by the utmost radical uncertainty: Sardinia. The crisis that broke out in 2007 constitutes the context of the Sardex.net circuit creation. Having studied the WIR case, the Sardex.net's promoters sought to implement the arguments of Proudhon and Gesell (Gesell 1958 [1916]) ${ }^{8}$ about the role of money and credit, trying to activate a tool that would put into practice that theoretical system. In 2009, after six months

7 The financial management of WIR Bank is extremely balanced and could be adopted by our cooperative credit banks as well, without questioning the principles from which they derive their raison d'être. As Giancarlo Beltrame demonstrates in his insightful study: "The commissional income deriving from the management of the WIR circuit turns out to play a double role in supporting revenue generation: countercyclical to compensate for the drop in interest rate differential, but also, and more importantly, structural because the commissional component of the WIR circuit proves to be the most stable in the construction of the intermediation margin and has been able to settle at a contribution level which is decisive for the characteristic net profitability of WIR Bank" (Beltrame 2014, 91).

${ }^{8}$ See also what John Maynard Keynes writes about Gesell in chapter 23 of General Theory (Keynes 1936). 
of preliminary meetings with the regional companies, especially in the area of Cagliari, whose purpose was to form a critical mass, the circuit came to life. The objectives pursued by the Sardex.net network are to strengthen communities, increase prosperity and stimulate spending in the Sardinia region. As Sartori clearly shows:

\begin{abstract}
Sardex entails the creation of ties among actors that did not know each other before, leveraging or filling the void of the lack of a pre-existing rich relational network. The cultural and social embeddedness of economic action also appears clearly in a context of low levels of social capital with the fostering of a favourable context for market exchange and community building. Sardex is an integrated network of economic and social ties where a good balance of self-interested and cooperative actions has been reached (Sartori 2016, 11).
\end{abstract}

The regulation of trade takes place between circuit members and through the use of Sardex credits. Its exchange ratio to Euro is 1:1. Upon registration each member becomes the holder of the bank account and gets a credit line at a zero per cent interest and a purchasing card that works within the circuit. The website allows all the members to create a profile that may be used to communicate all information about their business, like their products' descriptions, or to search for other registered companies and then carry out all the transactions agreed between the parties. The most relevant relations, however, are those offline. Each company has the possibility to consult with a broker who offers advice and helps to manage transactions in Sardex. The broker tries to facilitate exchanges between companies by analysing the debt and credit positions in the circuit: growth in the number of transactions must go hand in hand with maintaining a regular level of circulating credit. In point of fact, the idea is to maintain a stable money supply per capita, able to sustain the volume and number of transactions. Credit lines are provided with a collateral consisting in a set of goods made available by the company that joins the circuit. We can imagine the collateral as the "warehouse" of the company. Just as in the case of the WIR circuit, risk management becomes risk-sharing. However, if the debt position is not hedged within twelve months by the sale of the new goods and therefore the attainment of sufficient credits, it has to be hedged in Euro. If such an event does not occur, the regular credit recovery procedure is launched. These are obviously extreme cases, which have always been avoided thanks to 
the workings of the Sardex.net commercial area: in fact, advisors oversee the circuit's acquiring of potential buyers of products by an endangered company.

Moreover, risk management also provides for hedging debt positions ex post; such debt is divided among all the members of the circuit and is to be seen as a kind of a "solidarity tax". 9

Sardex credits lose value at the same pace as the euro: this inflation is already a kind of negative interest that weighs on the currency. Therefore, contrary to the claims of that monetary crank Silvio Gesell, Sardex does not add a further negative interest to surplus positions.

It is a matter here of a local credit circuit, one that is business-oriented and aware of the relevance of local demand. For this reason, in June 2012 Sardex launched a business to employee (B2E) pilot project that in fact entails the possibility of creating a diversion in the liquidity flow, which may harbinger the multiplicative effects on consumption demand that characterizes the circuit (according to fig. 2).

Fig. 2. $A$ circuit $B 2 B+B 2 E$

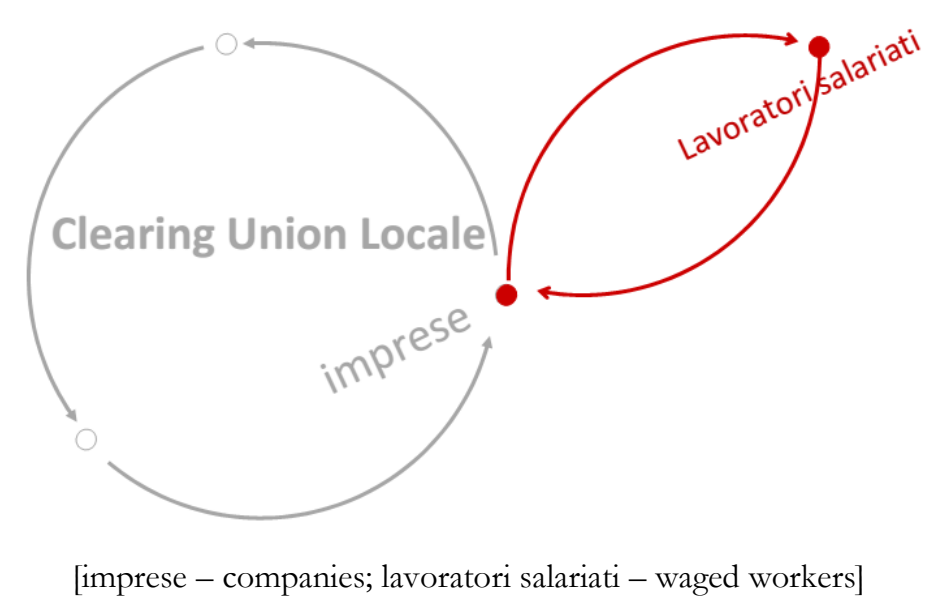

The project involved ten companies in the Cagliari zone. According to its principles, salaries are paid partly in Sardex credits. The employees of the companies can voluntarily join the Sardex.net circuit and create their own personal accounts, on which they would receive part of the salary, bonuses, wage advances or reimbursements. For example: if an employee needs an advance for an unexpected expense, he or she can make use of the Sardex.net

\footnotetext{
${ }^{9}$ However, it should be emphasised that the credit lines are small: the quotes vary from minimum 1000 to maximum 20000 credits. On this subject see Mellone's (2013) arguments.
} 
circuit and thus avoid drawing from savings or turning to other financial institutions that would demand high interest. An employer who pays in advance with the Sardex credits will obtain benefits in terms of monetary savings in the following months. The system thus also benefits, as the Sardex credits received from the employee have to be spent within the local circuit.

83 out of 100 employees involved in the experiment chose to open an account in Sardex. The average expense of the employees stood at 500 credits, a conspicuous amount. There were employees who spent 100/150 credits and others who received nearly their entire salary in these credits (for example those who were renovating their houses and found good suppliers within the circuit). The idea is to launch this B2E on a larger scale, but in order to do that a network is needed that would guarantee a reasonable possibility of spending (an employee cannot be forced to travel $40 \mathrm{~km}$ to buy something). That network would reflect the network of common currency. We are also assembling a capillary spendability in other centers of the province, outside of the Cagliari zone. Obviously, in the first phase, which was a B2B exclusively, it was not necessary. We are completing the technical tools for the next phase, which will consist in accommodating individual consumers in the circuit. The consumers will guarantee the companies their most precious asset: their loyalty and purchasing power. By choosing to buy within the circuit, they will receive a topup of their commercial credits. 10

In its first year, 237 businesses traded just over $€ 300,000$ in Sardex. In 2017, more than 3,500 businesses and 2,000 individuals had exchanged 140 million worth of transactions. Today Sardex arouses extreme interest in the business world. According to various media, it is one of the 28 Italian start-ups whose value exceeds one million euro. ${ }^{11}$ The expansion strategy of the circuit aims, firstly, to consolidate the regional Sardinian economy through promoting experiments involving public administrations and, secondly, at valorising skills developed over time through forms of consultancy to develop the system in other regional entities. We thus face the situation where meeting collective social needs still remains in the background. All in all, this depends on including the public administration in the circuit.

10 Federica Mellone's interview with Carlo Mancosu, January 2013, in charge of communications in Sardex.net (Mellone 2013, 94-96).

11 See, for example, the interview with Carlo Mancosu, published in Repubblica.it on 23 June 2014, http://www.repubblica.it/next/2014/06/23/news/dalla_sardegna_al_resto_d_italia_sardex_inventa_la_monet a_complementare_abbiamo_ripensato_1_economia-89771112/. 
For, by employing multilateral clearing houses, the public administration would be able to create greater liquidity in Sardex, which it could then forward to promote its social policies in the areas that its manages.

Massimo Amato and Luca Fantacci fostered a project called Libra, the name for a local multilateral clearing house able to give voice directly to workers' associations and to the variegated non-profit world, meaning it was not conceived merely as a B2B. Between 2010 and 2013 in Nantes these two scientists made sure all the conditions were there for the realisation of the project. The project consists of a credit circuit and a monetary circuit integrated in a unique local financial system. The credit circuit is designed as a clearing house meant to support exchanges between companies. Similar to the Sardex case, each company belonging to the circuit has a bank account denominated in the local currency (SoNantes), which may be used to pay or to receive payments from other companies within the circuit. Each company's balance can therefore be either negative or positive. There are limits set on the budgetary imbalances of each company, which means they are charged not only for negative balances, but, symmetrically, also for positive ones. The companies may use their positive balances to remunerate their employees, thus fostering the local monetary circuit, which consists of two sub-circuits: in the first one, companies transfer a part of their assets in local currency to their employees as a supplementary remuneration. The employees have epurses at their disposal, thus allowing them to use the local currency in transactions with other participating companies. If a citizen-employee does not spend all of his or her local currency, a part of the remaining balance is periodically transferred to a non-profit organisation chosen by this individual from among those participating in the circuit.

Thus, the local currency then enters the second sub-circuit, in which the non-profit organisations, which are also equipped with specific e-purses, spend the amounts they have received (see fig. 3). This type of monetary circulation especially helps to attenuate the paradoxical situation, characteristic for periods of crisis, in which unsold goods and squandered work capacity co-exist alongside unmet needs. 
Fig. 3. The Libra circuit

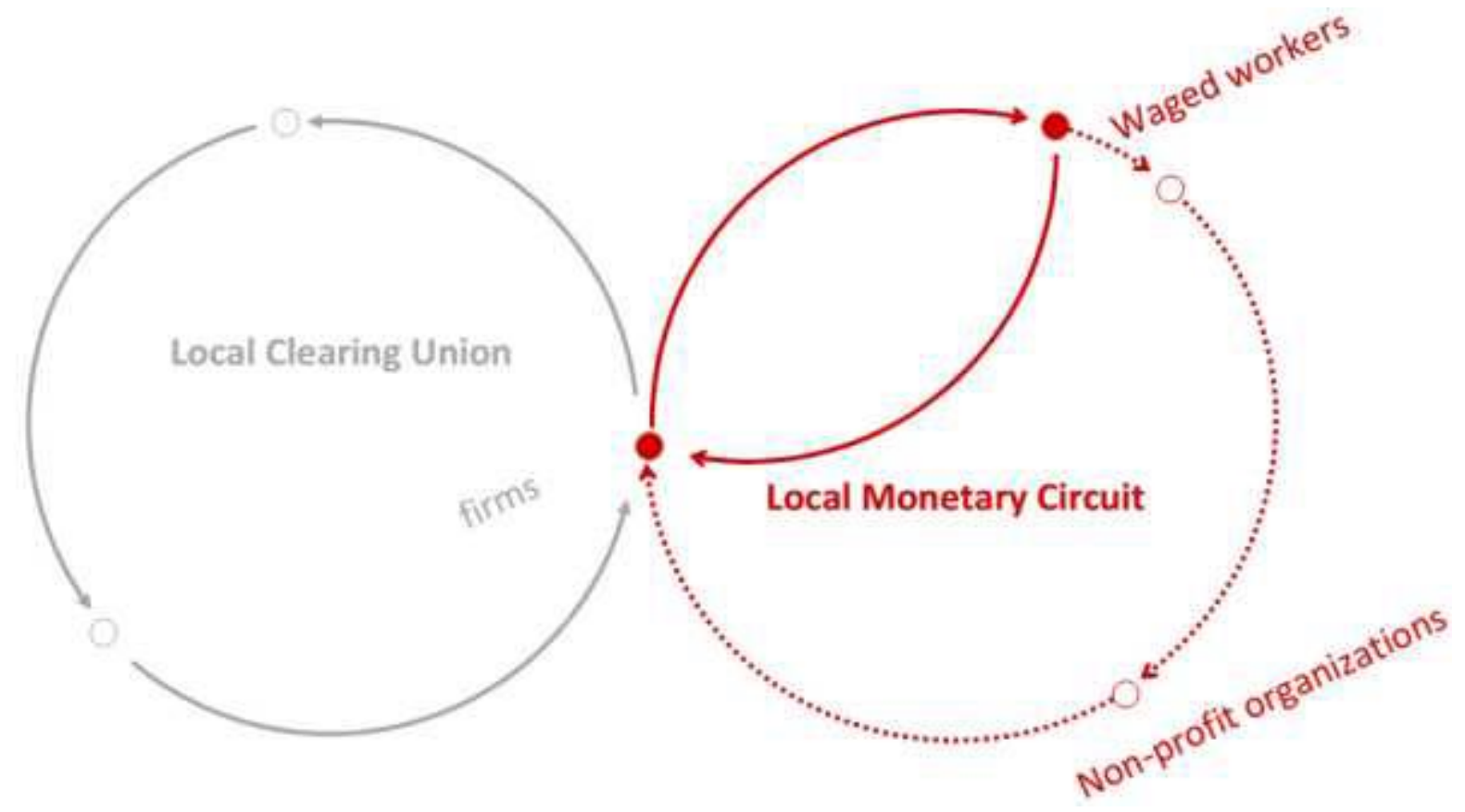

Source: Amato. and Fantacci (2012b, 162).

Thus a local finance system is created capable of producing a set of benefits for the community. The credit granted in the local currency is completely transformed into local demand. To the individual categories of involved subjects, such a system would offer a low cost form of financing, an instrument for bargaining, and supplementary way of remunerating labour as well as a source of financing for the third sector to meet the growing needs of social services. Non-profit organisations are actually entities that are structurally in deficit, because they are characterised by higher costs than revenues. The Libra circuit offers them a financing channel that may supplement or replace traditional methods by increasing the delivery level of social services or by relieving the pressure on public budgets, thus promoting planning by reducing high levels of uncertainty and, presumably, generating broader participation. The implementation of such a system thus has an explicit and wide-ranging political value, one in keeping with the spirit of subsidiarity and mutuality. Cooperation in a local economic zone can be reinvented in an unprecedented way, such that it would liberate the relationship between the free market and decisions regarding social policies from profitability pressures. Moreover, the cost reductions involved in financing the working capital coupled with an increase in demand - which in this scheme may potentially meet the new needs of the world of non-profit organisations - could also allow companies and the public 
administration to increase their volume of long-term investments in euro, if they could count on better financial resources and expect increasing returns. A growth in qualified investments, given the appropriate productive specialisation of a local economic system, may stimulate aggregate demand and local income. ${ }^{12}$ The adoption of a local currency stimulates income, and the surplus may be distributed among companies and workers via plant-level bargaining. Public administrations, on the other hand, could further benefit from the existence of a clearing house as participants, since a clearing house functions as a low-cost creditor. This opens the way to fund public projects - so often barred by all the various financial restrictions characterising austerity policies - avoid the delays in payments to suppliers that weigh heavily on local economies and that, ultimately, reduce the use of costlier and riskier financial instruments, such as derivatives. In short, this institutional structure may efficiently bring out old and new spaces of mediation, i.e. old and new forms of democratic confrontation. The same criterion of crediting non-profit organisations can open a space for discussion and mediation for all those who care for collective needs. ${ }^{13}$

Given the highly defined nature of the project, we might presage the creation of real "political technologies": this expression is used to indicate processes of transformation and the structure that enables a consolidation of political debate, in this case an alternative monetary circuit. The integration of the local financial system in Nantes was introduced as a new social contract between the public and the private, business and workers, the world of production and the world of associations. It was launched at a time when economic tensions threatened to compromise social cohesion. ${ }^{14}$ The cooperation between the Italian founders of the project and the local institutions nonetheless failed at the threshold of the operational phase. The operational phase of SoNantes, on the other hand, has been delayed several times. ${ }^{15}$ To date, despite SoNantes being a part of the pilot currencies of the CCIA European Interregional Project, ${ }^{16}$ the complex nature of this political experiment has resulted in an extremely slow working out of agreements between the parties involved: the Crédit

12 On this matter may the reader permit me to refer to Lucarelli and Romano (2016).

13 It is not out of the question that non-profit associations could be replaced by a municipal fund for social services. The urban precariat could thus reclaim a territory for direct representation.

14 See e.g. La Monnaie Eutopique, 15 December 2011, https://www.youtube.com/watch?v=2KJnk-Z2_tY

15 On the reasons for the continuous delays see the speech by Massimo Amato at the conference which took place in Macao, Milan 21 June 2014: http://quaderni.sanprecario.info/2014/07/convegno-moneta-delcomune-introduzione-di-massimo-amato/.

16 Community Currencies in Action, see http://community-currency.info/en/currencies/sonantes/. 
Municipal de Nantes, the local Chamber of Commerce, the City of Nantes and the intermunicipal metropolitan structure. The project looks like a top-down procedure whose outcomes raises numerous doubts and whose strategies seem aimed at obtaining the biggest possible electoral support and are therefore guided by a principle of political calculation. In this case, democratic participation in the decision-making process, which is a linchpin of gaining trust in the complementary currency, seems to be "the great absentee".

The focus on social needs as well as the awareness that the construction of a monetary circuit poses also the challenge of democratic participation, characterizes another interesting French experience: Sol Violette in Toulouse. ${ }^{17}$ The Toulouse experience - which, bear it in mind, is not a clearing union but an alternative monetary circuit - began in May of 2011, when the city launched a six-month-long experiment. Since 2007, the Sol model had existed as a political objective and was promoted by a group of activists called "Reconsidérer la richess", who based themselves on the thought of Patrick Viveret. In 1998, inspired by Been₹, an international loyalty system intertwined with e-commerce that functioned between 1998 and 2001 (Fare 2011), Viveret conceived a loyalty system limited to the social economy and that works online. However, the project has left the web and, little by little, has transformed into a digital currency used in the context of social economy, the Sol.

Before Sol Violette, another experiment was performed in Toulouse that had failed: a digital currency that was introduced by a top-down procedure without adequate citizen participation. The project started working only after attention was turned not exclusively to the demand for a complementary currency as such, but also to the involvement of various entities that establish an alternative political, productive and social cooperation. At the beginning there were 30 companies of sustainable development operating in the field of social economics, three district representatives and 150 individuals. The initial emission amounted to 27000 Sols (27000 euro). ${ }^{18}$ To date the local authorities cover most of the operating costs: 80 per cent is financed by the Metropolitan government of Toulouse, 15 per cent by private foundations and the rest by the participants. After paying the membership fee, members of the circuit can exchange their euros for Sol Violettes at local branches of

17 http://www.sol-violette.fr/

18 In October 2013, there were 1600 individual users and 130 firms and associations. The total amount of Sols in circulation was 47918. See Bilan 2013 Sol Violette, 60, download from http://www.sol-violette.fr/solviolette/le-projet/documentation. At the end of 2017, 2327 citizens and 258 firms and associations used Sols. The total amount of Sols in circulation was 54292. See Bilan 2017 Sol Violette, 4. 
Crédit Municipal or Credito Cooperativo. The banknotes are accepted by the companiesmembers of the circuit (in 2013 there were about 50 food companies) but they can also be spent on tickets for public transport and on other types of local and cultural services. A Local Committee (CLAS) organises the decision-making processes, convening the Conseil des Collèges, which represent stakeholders, General Assemblies and plenaries: regional institutions and their administrations, non-profit associations and their beneficiaries, social and solidaritybased social structures and their users, organisations and/or producers focussed on long-term development and their clients, banking and non-bank financial institutions - they all gather in the Colleges where they adhere to collective and democratic method of discussion and participation that is attentive to gender representation.

Fig. 4. Model of governance of Sol Violette in Toulouse
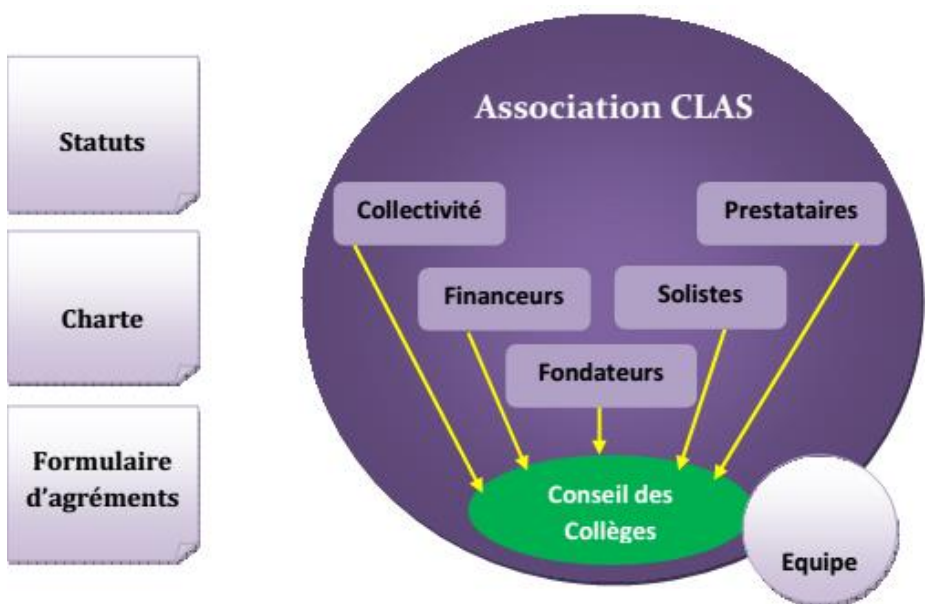

Source: Bilan Sol Violette. Phase d'experimentation mai 2011 - décembre 2011, Tolosa, p. 15.

[Statuts - Statutes, Charte - Charter, Formulaire d'agréments - approval forms, Collectivité - Collective, Prestataires - Recipients, Financeurs - Financers, Solistes - Adherents, Fondateurs - Founders, Equipe - Staff]

This governance model is absolutely vital for the project's success (see fig. 4). ${ }^{19}$ The case of Sol Violette is interesting mainly for three reasons:

a. it is a currency that cannot be accumulated (a demurrage à la Gesell is applied, i.e. a negative interest tax on Sols that are accumulated and not spent within a reasonable time);

b. cooperation pre-exists the monetary circuit, at least from the point of view of the adherence to a series of ethical and economic objectives and imperatives;

19 The governance model is meticulously explained in Bilan Sol Violette. Phase d'experimentation mai 2011 - décembre 2011, downloadable from: http://www.sol-violette.fr/sol-violette/le-projet/documentation. See also the movie: Sol Volette. L'éclosion d'une monnaie, http://vimeo.com/45862277. 
c. the currency serves also as a form of income distribution: there is a project which establishes a payment of 30 Sols per month to an unemployed association (120 families). The redistribution is done on a case-by-case basis. This spurious form of guaranteed minimum social income seems to invigorate the construction of the circuit. However, this circuit remains limited by a cautious, if not meagre, monetary emission.

The currency is a social relation even before it is a technology, which means it is not socially neutral, but at least partially crystallizes social relations which work just like institutions. If this does not occur, even the best structure imaginable - for example the Libra circuit that inspired SoNantes - does not produce good results. And vice versa: even when the technology is suboptimal and the exchange instrument has a limited potential of diffusion as in the Sol Violette case - there may emerge a stable institutional structure with a potential for improvement through confrontation and mediation between circuit members. It does not seem that an opposition arises against the official monetary circuit in any of these cases. We are rather dealing with a form of experimental democratic accountability, one that may evolve and take a different shape: in the Sardex case we see a possible path of development according to which the business vision tends to prevail in a way that brings back spaces of mediation between capital and labour. In the case of Sol Violette we see new institutional structures whose main goal is to meet unsatisfied social needs, but needs that are still determined by the choices of a local authority that guarantees the ongoing emission of the complementary currency.

\section{Some notes on crypto coins}

The crypto coin experience presents a far more complex set of problems than local complementary currencies. First of all, the coin experiments are explicitly motivated by dissent against the state. This dissent presents two paths that are characteristic of anarchism: the first gives rise to the political inclinations of Friedrich von Hayek (Hayek 2001), while the second evokes the anti-authoritarian socialism typical of the thought of Noam Chomsky, but also - with all due differences - of the thought of a fair-share of intellectuals who, starting out in the so-called Autonomia, have developed political categories that are now being put to work in the debate on municipality rights (see Lotringer and Marazzi 2007, Chignola 
2012, Marella 2012, Negri 2012). The currencies competition analysed by Hayek is based on the idea that all monopolies, especially those on money emission, are uneconomical because they prevent the progressive reduction of costs guaranteed by competitiveness.

I have come to the firm conclusion that a free economic system will not be able to function effectively, nor will it be possible to suppress its worst downsides or contain the continuous growth of administration, if a monopoly on money emission is not be taken away from the government itself. I consider this objective to be so vital that it would, I believe, be essential for a free people's constitution to establish such a principle, with some sort of a special clause, such as: "Parliament will not sanction any law that violates any person's right to have, buy, sell or lend lend, stipulate and enforce contracts, calculate and hold their balance sheets, in the preferred type of currency" (Hayek 1986, 523).

I will not dwell here on the analytical weaknesses of Hayek's arguments. Suffice it to say that the rhetoric on free banking that has accompanied banking deregulation has often translated into the formation of powerful oligopolies. The great technological and social innovation characterising crypto coins consists in the central position assumed by peer to peer: the emission of these instruments, which conventionally may be used as means of payment in online transactions, does not need any emitters. It enables the diffusion of purchasing power independent from any traditional form of control, because there is no bank behind it. It is something that even Hayek did not foresee and that shows above all the ability of the online exchanges to define a virtual territory which provides a contact after contact between more currencies, able to consolidate and strengthen extant social relations beyond state control. However, this does not mean that the system that begins to take shape presents the characteristics of an alternative to capitalism. The ghost of Hayek lurks!

We shall dwell, however, on some aspects of the technologies behind crypto coins. Let's take the case of Bitcoin (Nakamoto 2009). As is known, the Bitcoin production is possible thanks to an algorithm: purchasing power is transmitted from one wallet to another with use of a wallet's unique identification code. The exchange happens only when both wallet's codes are recognised..$^{20}$ Once the transaction is completed, the Bitcoin system has to confirm it. The verification process is called mining and is conducted by the users of

${ }^{20}$ Correctly, it was suggested to me to clarify that in theory one can send bitcoins to a never-before-used, but valid in crypto-graphical terms, address. Such funds are "burnt". This is unlikely, however, as there is a checksum to prevent this situation. 
the system themselves: they share their computer's power, so that the mining process may be performed. Thus the legitimisation of the exchange fuses with the creation of a new purchasing power, because users who make themselves available to run algorithms that constitute the verification process receive a fraction of Bitcoin as a reward. ${ }^{21}$ The whole process of creation and exchange of these units of account has also to maintain a certain level of security, which is provided by blocks of information (blockchains) that prevent users from taking possession of other user's wallets. It is a sort of a public ledger. Besides, the timestamp server helps to avoid the same Bitcoin being used in different online commercial operations. As opposed to other online payment systems, like credit cards or Paypal, which cannot function without a bank account or some other form of money deposit, Bitcoin does not force its users to deal with intermediaries, whose presence affect the total cost of a commercial operation. However, the transactional function does not exhaust the characteristics of this experience. The enormous diffusion of Bitcoin and to an even bigger extent the volatility of its value, depends on the fact that over time crypto coins have been perceived mostly as financial products. Yet, due to its construction, Bitcoin can only be deflationary in the long term. It exists within a finite range of possibilities, since its emission (mining) becomes more and more difficult because the computing power necessary for the calculations resolving the algorithms increases in parallel to the growth of the number of Bitcoin transactions. No one can raise the amount of Bitcoin beyond a numerical limit that can already be estimated. How will markets react when the Bitcoin becomes scarce? What will happen to those who have accumulated these assets for speculative motives? And what will happen to those who use it for mere transactional purposes?

However, in my opinion, the most appropriate question, is the following: is it possible to imagine a world where the rentiers who accumulated Bitcoins in view of holding gains would be crowded out by a real revolution to come: one in which an alternative monetary circuit that is immune to speculative logics and diffused in communities of increasingly autonomous individuals is capable of creating a new monetary thinking?

At least part of the backers community that has developed this and other more or less similar projects did not perceive them either as instruments aimed to deprive governments of their power, as support for a competitive private market for different currencies (Jaromil 2014) or as a speculative asset able to be harnessed to favour a redistribution of resources

21 This mechanism has already been explained on many occasions, notably by Meggiato (2014). 
controlled by few, or even less so as fraud or as a means to enforce the Deep Web.22 "In the hacker mentality passion is more important than money. Social motivation is part of his job, the hacker works for the society" (Gruppo Equipo 2008). Hacker ethics is contrary to processes that are exclusive and introduced and modified by only a few. It is founded on an open-source ideology that is meant as a self-regulative process that all control. Hackers see themselves and behave as a horizontal community that quickly passes from the conceptual to the creative stage. Ideas are never imposed on others and all the attention is paid to the growth of the individuals to create space for the development of all and the development of parallel solutions (Himanen 2003) (see fig. 5).

Fig. 5. Hacker logics

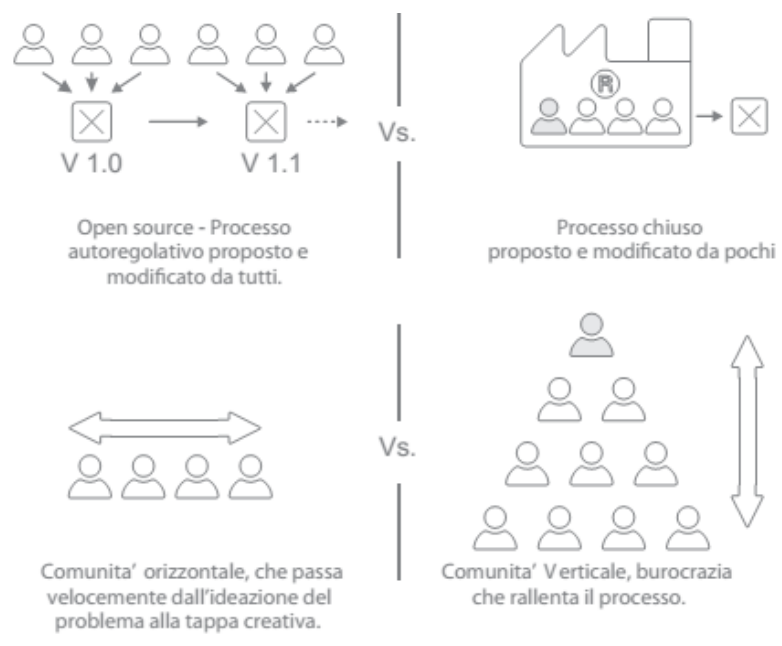

Source: Gruppo Equipo (2008, 9).

[Open source - self-managed process advanced and modified by all.

Vs.

Closed process advanced and modified by few;

Horizontal community, which quickly passes from ideation of the problem to the creative stage.

Vs.

Vertical community, bureaucracy which slows the process.]

22 The value of Bitcoin was highly affected, both positively and negatively, by the Silk Road, anonymous marketplace, an online commercial platform that used Bitcoin as means of payment. It operated using hidden Tor services and was shut down by the FBI for the first time on 3 October 2013 and definitively on 6 November 2014. 
Given the logics that characterise at least a part of the hacker community, crypto coins, and Bitcoin in the first place, are not themselves objectives. Instead they are understood to be a work in progress, a symbol of protest for network neutrality. Crypto coins could then constitute a social experiment whose goal would be to construct a new constituent sovereignty. We are certainly in the realm of the possible, and we are also in a problematic environment that needs to take material form to avoid being confined to a merely virtual reality. There is no doubt that crypto coins have incited interest in the possibility of creating purchasing power through open-source software. What seems even more interesting is the fact that they represent the means to substitute the peer to peer philosophy by so-called speculative motive. The tendency to accumulate wealth seems somehow destined to legitimise precisely those social interactions that are propelled by a social imaginary (in the sense of Cornelius Castoriadis) ${ }^{23}$ and social behaviours that are deeply hostile towards the authoritarian processes imposed by financialisation. Yet, these potentialities cannot remain confined to the Internet, if what is aspired to is a real capability to create a political being able to participate in decisions related to the production, distribution and consumption of resources.

\section{Conclusions}

In the light of the above considerations, the institutional nature of money comes clearly to light. Like all institutions, money has to be understood, created and experienced as a complex set of relations able to withstand the weight of its own structure, able to survive, able to last. The longevity of a monetary circuit does not depend exclusively on mere issues of social or management engineering. Trust is decisive. Trust is a point of departure for dissolving one of the Gordian knots that has been recurring from the beginning of my essay, that of sovereignty.

Monetary mediation provides a common area for taking decisions on the value of reality, thus allowing the management of debt and credit relations. According to André Orléan, money may become an instrument of accounts control as an anthropological

\footnotetext{
23 On this point see Kavoulakos 2000
} 
expression of an absolute desire. ${ }^{24}$ For money to materialise, the problem of peaceful coexistence has to be resolved in advance; also required is some kind of a founding act that would abolish all forms of violent expropriation. In other words, money acts as a form of sovereignty (Orléan 2006) - a form that does not necessarily coincide with the state form.

Alternative monetary circuits may be conceived in different ways and therefore used for different purposes. Complementary currencies based on the clearing principle appear better able to cope with change than other monetary systems. In other words, they are resilient, especially if they are able to create and ensure an environment conducive to constructive economic and social interaction with no imposition of top-down procedures (Lucarelli and Gobi 2016). Theoretically, they can represent mechanism of exodus or defection from the oppressive authority that forces subjects into the perverse dynamics of continuously growing indebtedness. This aspect, however, is not found in the above case studies:

- the Sardex experience aims in this phase at valorising skills that have been developed over time through forms of consultancy in other Italian regions;

- the SoNantes project seems to be a top-down procedure, the outcome of which raises numerous worries;

- Sol Violette represents a set of new institutional structures whose main goal is to satisfy local social needs, but which are strictly dependent on local political authority.

Crypto coins are virtual currency schemes that cannot be considered full forms of money. They are a digital representation of value. On the other hand, they can be promoted with the aim of explicitly hurting state's monopoly on money emission. They can also be promoted and coordinated by a state government with a view to introducing a new balance of powers between different levels of authority (Lucarelli and Gobbi 2016). All in all, the results depend on the collective wisdom of the decision-makers controlling these processes.

Laurent Baronian and Carlo Vercellone (2015) underscore that money that does not obey capitalist logics should above all be used to finance welfare services and guarantee

\footnotetext{
${ }^{24}$ Following René Girard's perspective, violence is nothing if not the signifier of the absolute, the form and substance of absolute desire. André Orléan considers money as a form of violence (Fumagalli and Lucarelli 2011).
} 
universal access to those services, and thus used to foster a model of development based on knowledge and on production by the people for the people.

Can such a process be imagined, starting from a form of coordination between the alternative monetary circuits already at work? It is a question that may be as well phrased as follows: how may the alternative monetary circuits enhance a reproduction of labour power that would not succumb to capitalist logics, and, more generally, to logics of expropriation?

Can we imagine that the knowledge acquired from the world of crypto currencies merges with the lessons learned from the reviewed case studies on local monetary circuits could bear fruit in the form of creating technologies and skill sets more powerful than any speculative dynamics or political calculation?

If we have an institution of significant magnitude able to remunerate adequately the productive relations underway in one's place of residence, it may act in concert with the satisfaction of collective needs that currently remain unexpressed.

Experiments using crypto coins on the one hand - if interpreted through hacker ethics - and with clearing unions on the other - provided they embody a truly participatory model of governance - seem to place us on the brink of the future politics, whose problematics were hinted at by Luciano Ferrari Bravo in one of his last works. His reflection did not pertain to the common understood as a juridical principle (Negri 2010) (an expression I consider abused and that risks spreading confusion regarding these extremely important issues), but rather to federalism:

the framework of post-Fordist production and society seems to be naturally predisposed to accept - for the globalized government's own needs - the conceptual and institutional resources offered by a sufficiently broad concept in a spirit of federalism. [...] But the metaphor of a network, of a circular interconnection of flows and processes, does not authorise envisioning a social space structured symmetrically and horizontally (i.e. devoid of any problems regarding the authorities) [...]. The network does not extend along a two-dimensional plan, its cruxes are not equidistant nor equivalent. It rather shapes a general process of concentration of noncentralized power. [...] In the same sense a very general hypothesis could be formulated about neo-federalism or postmodern federalism as an institutional key for global system governance structures. [...] However, viewed from a bottom-up perspective, it allows us to recognise a constraint (but also an opportunity) that already lurks on the horizon of a future politics, that is the constitutive connection between global and 
local dimensions in the processes of identity formation and in the determination of the political agenda in the new century's public sphere (Ferrari Bravo 2001, 122-123).

On the other hand, when we talk about money, we are also talking about sovereignty, and when we talk about sovereignty, in play also is the capacity to govern that a collective is able to express, recognising the need for appropriate mediations both within itself and outside. ${ }^{25}$

${ }^{25}$ I must thank numerous people for their encouragement, teachings and exchanges of ideas, which kept these reflections alive without allowing them to sink into the irrelevance that so often characterises the economic sciences or to fall prey to the self-referentiality that often characterises politics. Massimo Amato, Giancarlo Beltrame, Emanuele Braga, Francesca Bria, Lucia Bonacci, Carmelo Buscema, Orsola Costantini, Luca Fantacci, Andrea Fumagalli, Gianluca Giannelli, Alfonso Giuliani, Lucio Gobbi, Giorgio Griziotti, Emanuele Leonardi, Christian Marazzi, Carlo Mancosu, Warren Mosler, Francesco Pezzulli, Denis Roio aka Jaromil, Marco Sachy aka Radium, Angelo Salento, Tiziana Terranova, Carlo Vercellone, Akseli Vircanen. Thanks also to the companions and friends of the Spazio di Mutuo Soccorso-Ex Mondino in Pavia (30/11/11), Rifondazione Comunista of Marsciano (3/8/12), Uninomade (13/9/12), Teatro Valle Occupato (5-6/10/12), Punto Rosso (30/10/12 and 2/12/14), SMS-Unipop of Milan (21/11/13), Sudcomune (10/3/14), Macao and Effimera (21-22/6/14) and Hackmeeting (28-29/6/14) who in these years have invited me to present and discuss my reflections on the topics covered by these notes. For the same reasons I must thank the Municipality of Bergamo (21/1/13), the BCC of Calcio and Covo $(28 / 3 / 14)$ and Robin Hood Minor Asset Management (17-20/11/14). I would also like to express my gratitude towards Giancarlo Beltrame, Carmelo Buscema, Orsola Costantini and Adelino Zanini for their comments on the first version of this text. Thank you also to the two anonymous referees of this journal who contributed to improving a previous version of the article. Finally, I want to thank Marica Fuso Nerini, Federica Mellone, Gianluca Negro, Davide Pasini, Eleonora Semeghini and Cristina Toti: their theses, which I supervised, are remarkable contributions to the study of complementary currencies and they have been extremely useful in the elaboration of this article. 


\section{References}

Amato, Massimo, and Luca Fantacci. 2012a. The End of Finance. Cambridge: Polity Press

Amato, Massimo, and Luca Fantacci. 2012b. Come salvare il mercato dal capitalismo. Idee per un'altra finanza. Roma: Donzelli.

Baronian, Laurent, and Carlo Vercellone. 2015. "Moneta del comune e reddito sociale garantito." UniNomade 2.0. http://www.uninomade.org/moneta-del-comune-e-reddito-socialegarantito/.

Beltrame, Giancario. 2014. "BCC e territorio." In L'Europa dei territori. Etica economica e sviluppo sociale nella crisi. Eds. E. Leonardi and S. Lucarelli. Napoli: Orthotes.

Bianchi, Carluccio. 1982. "Moneta." In Dizionario di Economia Politica. Vol 5. Eds. G. Lunghini and M. D'Antonio. Torino: Bollati Boringhieri.

Chignola, Sandro (ed.). 2012. Il diritto del comune. Crisi della sovranità, proprietà e nuovi poteri costituenti. Verona: ombre corte.

Fantacci, Luca. 2016. The trap of liquidity: analysis and countermeasures following J. M. Keynes. Conference paper, 57th SIE Annual Conference, Milano October 20. http://www.siecon.org/online/wp-content/uploads/2016/09/FANTACCI.pdf

Fare, Marie. 2011. "The Sol: A Complementary Currency for the Social Economy and Sustainable Development." International Journal of Community Currency Research 15: 57-60.

Ferrari Bravo, Luciano. 2001. "Federalismo." In Lessico postfordista. Eds. A. Zanini and U. Fadini. Milano: Feltrinelli.

Fumagalli, Andrea, and Stefano Lucarelli. 2011. "Penser la crise et la sortie de crise. Les apports de André Orléan, et au-delà." European Journal of Economic and Social Systems 24(1-2): 195210.

Gesell, Silvio. 1958 (1916). The natural economic order. London: Peter Owen.

Gruppo Equipo. 2008. Pekeka Himanen. L'etica hacker e lo spirito dell'informazione. Analisi del testo. https://piratifirenze.files.wordpress.com/2015/05/booklet-equipo-letica-hacker.pdf

Hayek, Friedrich von. 2001. La denazionalizzazione della moneta. Trans. W. Marani and M. Finazzer. Milano: Etas.

Hayek, Friedrich von. 1986. Legge, legislazione e libertà. Trans. P.G. Monateri. Milano: Il Saggiatore.

Himanen, Pekka. 2003. L'etica hacker e lo spirito dell'informazione. Trans. F. Zucchella. Milano: Feltrinelli.

Jaromil, Denis Roio. 2014. Bitcoin, la fine del tabu della moneta. http://quaderni.sanprecario.info/2014/01/bitcoin-la-fine-del-tabu-della-moneta-didenis-jaromil-roio/

Kavoulakos, Konstantinos. 2000. Cornelius Castoriadis on Social Imaginary and Truth. Paper presented at the International Workshop "Social Theory and the Work of Cornelius Castoriadis", University of Crete, September.

http://ww2.fks.uoc.gr/english/cvs/kavoulakos/Kavoulakos\%20Social\%20Imaginary.pdf Keynes, John Maynard. 1923. A Tract on Monetary Reform. London: Macmillan.

Keynes, John Maynard. 1936. The General Theory of Employment. Interest and Money. London: Macmillan.

Lietaer, Bernard, and Margrit Kennedy. 2012. Monnaies régionales. De nowvelles voies vers une prospérité durable. Paris: ECLM.

Lotringer, Sylvère, and Christian Marazzi (eds). 2007. Autonomia: Post-Political Politics. Los Angeles: Semiotext(e). 
Lucarelli, Stefano, and Lucio Gobbi. 2016. "Local clearing unions as stabilizers of local economic systems: a stock flow consistent perspective." Cambridge Journal of Economics 40: 1397-1420.

Lucarelli, Stefano, and Roberto Romano. 2016. "The Italian Crisis within European Crisis. The Relevance of the Technological Foreign Constraint." World Social and Economic Review 6: 12-30.

Marella, Maria Rosaria (ed.). 2012. Oltre il pubblico e il privato. Per un diritto dei beni comuni. Verona: ombre corte.

Meggiato, Riccardo. 2014. Il lato oscuro della Rete. Alla scoperta del Deep Web e del Bitcoin. Milano: Apogeo.

Mellone, Federica. 2013. Le "monete complementari". Uno studio introduttivo. Dissertation, Faculty of Economics, Università di Bergamo, a.a. 2012-2013.

Nakamoto, Satoshi. 2009. Bitcoin: a Peer to Peer Electronic Cash System. https://bitcoin.org/bitcoin.pdf

Negri, Antonio. 2010. "The Law of the Common." Finnish Yearbook of International Law 21: $16-25$.

Negri, Antonio. 2012. Il comune in rivolta. Sul potere costituente delle lotte. Verona: ombre corte.

Orléan, André. 2006. "Monnaie." In Dictionnaire des sciences humaines. Eds. S. Mesure and P. Savidan. Paris: Presses Universitaires de France.

Papdimitriou, Dimitri B., and Michalis Nikiforos, Gennaro Zezza. 2014. Prospects and Policy for the Greek Economy. Strategic Analysis, February. http://www.levyinstitute.org/pubs/sa_2_14.pdf

Sartori, Laura. 2016. Sardex, a Complementary Currency that Shapes a New Financial Space. Conference paper, SubTheme "Organizing in the Shadow of Financial Power", General Theme "Organizing in the Shadow of Power", University of Naples. http:/ / sociologiaeconomica.it/wp-content/uploads/2017/02/sartori_SISEC.pdf

Studer, Tobias. 2006 (1998). Wir and the National Swiss Economy. Basel: The Wir Bank.

Virno, Paolo. 1996. "Virtuosity and Revolution: The Political Theory of Exodus." In Radical Thought in Italy: A Potential Politics. Eds. M. Hardt and P. Virno. Minneapolis: University of Minnesota. 
Stefano Lucarelli (1975) - Associate Professor in Economic Policy at University of Bergamo, where he teaches International Monetary Economics, Economic Policy and Economic Ethics. He is also Adjunct Professor at University of Calabria in the Ph.D. program "Politica Cultura e Sviluppo" and Invited Researcher at Centre d'Économie de la Sorbonne at -CNRS, Unit of Research 8174, Paris. His research projects include institutional economics, cognitive capitalism, monetary theory of production, financialization and complementary currencies. He published articles on these topics in, among others, Sustainability (2018), Applied Economics (2018), Cambridge Journal of Economics (2016), World Economic Review (2016), Theory Culture \& Society (2015), Moneta e Credito (2015, 2013), Journal of Evolutionary Economics (2014), Metroeconomica (2014), International Journal of Political Economy (2012, 2011), Review of Social Economy (2008). He has been involved as researcher in the DCENT European Project (https://dcentproject.eu/2013-2016). He is now part of the DECODE European Project (https://decodeproject.eu 2017-2020), where he is analyzing the institutional features of the digital commons with the CNRS research team led by Carlo Vercellone and Jean-Marie Monnier. His last book is titled Squilibrio (written together Roberto Romano, Ediesse 2017).

\section{ADRESS:}

Stefano Lucarelli

c/o Dipartimento SAEM

Università degli Studi di Bergamo

Via dei Caniana 2, uff. 250

24126, ITALY.

E-MAIL: stefano.lucarelli@unibg.ut

CITATION: Lucarelli, Stefano. 2018. "Between Money and Sovereignty: Is a New Monetary Thought Necessary for The Institution Of The Common?” Praktyka Teoretyczna 1(27): 226251.

DOI: $10.14746 /$ prt.2018.1.9

Stefano Lucarelli (1975) - profesor na wydziale ekonomii Uniwersytetu w Bergamo, adiunkt na Uniwersytecie w Kalabrii w programie studiów doktorskich "Politica Cultura e Sviluppo" oraz badacz w Centre d'Économie de la Sorbonne, CNRS. Jego zainteresowania badawcze obejmują ekonomię instytucjonalną, kapitalizm kognitywny, monetarną teorię produkcji, finansjalizację oraz waluty komplementarne. Opublikował artykuły poświęcone tym zagadnieniom m.in. w Sustainability (2018), Applied Economics (2018), Cambridge Journal of Economics (2016), World Economic Review (2016), Theory Culture \& Society (2015), Moneta e Credito 
(2015, 2013), Journal of Evolutionary Economics (2014), Metroeconomica (2014), International Joumal of Political Economy (2012, 2011), Review of Social Economy (2008). Brał udział w projekcie badawczym D-CENT European Project (https://dcentproject.eu/2013-2016). Współtworzy obecnie zespół badawczy DECODE European Project (https://decodeproject.eu 2017-2020), w którym analizuje instytucjonalne aspekty cyfrowych dóbr wspólnych wraz z zespołem CNRS prowadzonym przez Carlo Vercellonego oraz JeanaMarie Monniera. Jego ostatnia książka to Squilibrio (współautor: Roberto Romano, Ediesse 2017).

TYTUL: Pomiędzy pieniądzem i suwerennością: czy instytucja dobra wspólnego potrzebuje nowej teorii monetarnej?

ABSTRAKT: Rozpowszechnienie alternatywnych obiegów finansowych i kredytowych, w ramach których pieniądz faworyzuje oddolne formy zarządzania społecznym bogactwem, może ograniczyć proces wywłaszczenia spowodowany anormalnym poziomem zadłużenia, charakteryzującym w coraz większym stopniu systemy gospodarcze. Autor artykułu proponuje analizę czterech przypadków zastosowania walut komplementarnych, które rozpowszechniły się w Europie po ostatnim kryzysie, dokonując przy tym rozróżnienia między walutami lokalnymi (Sardex, Sonantes i Sol Violette) oraz crypto coins (Bitcoin). Wykorzystanie monetarnego know-how, ożywiającego różne przypadki zastosowań walut komplementarnych (w rodzaju crypto coins i lokalnych izb rozliczeniowych), może pozwolić na przemyślenie pieniądza jako instytucji społecznej. W artykule refleksji poddane zostały trzy zagadnienia: 1. „technologie polityczne”, z których składają się alternatywne obiegi monetarne; 2. charakteryzująca je demokratyczna partycypacja w procesach podejmowania decyzji; 3. znaczenie suwerenności, które te technologie potencjalnie mogą definiować.

SLOWA KLUCZOWE: waluty komplementarne, Bitcoin, Sardex, Sol Violette, SoNantes, dobro wspólne. 